\title{
Correction to: GLP-I Secretion in Healthy and Diabetic Wistar Rats in Response to Aqueous Extract of Momordica charantia
}

\author{
Gulzar Ahmad Bhat ${ }^{1}$, Haseeb A. Khan ${ }^{2 *}$, Abdullah S. Alhomida ${ }^{2}$, Poonam Sharma ${ }^{3}$, Rambir Singh ${ }^{4}$ \\ and Bilal Ahmad Paray ${ }^{5}$
}

\section{Correction}

Following publication of the original article [1], the authors reported that there was an error in the acknowledgements. In this Correction, the incorrect and correct acknowledgements are shown.

Originally the acknowledgement has been published as:

We are thankful to Department of zoology, Hemvati Nandan Bahuguna Central University Garhwal Uttarakhand, India, for providing necessary facilities.

The correct acknowledgement is:

We are thankful to Department of Zoology, Hemvati Nandan Bahuguna Central University, Garhwal, Uttarakhand, India, and Innovation Centre, Bundelkhand University, Jhansi, India for providing necessary facilities.

\begin{abstract}
Author details
'Department of Zoology, HNB Central University Garhwal, Srinagar, Uttarakhand 249161, India. ${ }^{2}$ Department of Biochemistry, College of Science, King Saud University, Riyadh 11451, Saudi Arabia. ${ }^{3}$ Department of Zoology, Indira Gandhi National Tribal University, (A Central University), Amarkantak M P 484887, India. ${ }^{4}$ Department of Biomedical Sciences, Bundelkhand

University, Jhansi, UP, India. ${ }^{5}$ Zoology Department, College of Science, King

Saud University, PO Box 2455, Riyadh 11451, Saudi Arabia.
\end{abstract}

Received: 24 May 2018 Accepted: 30 May 2018

Published online: 06 June 2018

\section{Reference}

1. Bhat GA, et al. BMC Complement Altern Med. 2018;18:162. https://doi.org/ 10.1186/s12906-018-2227-4.

\footnotetext{
*Correspondence: bparay@ksu.edu.sa

2Department of Biochemistry, College of Science, King Saud University,

Riyadh 11451, Saudi Arabia

Full list of author information is available at the end of the article
}

(c) The Author(s). 2018 Open Access This article is distributed under the terms of the Creative Commons Attribution 4.0 International License (http://creativecommons.org/licenses/by/4.0/), which permits unrestricted use, distribution, and reproduction in any medium, provided you give appropriate credit to the original author(s) and the source, provide a link to the Creative Commons license, and indicate if changes were made. The Creative Commons Public Domain Dedication waiver (http://creativecommons.org/publicdomain/zero/1.0/) applies to the data made available in this article, unless otherwise stated. 